\title{
Interfacial partition of plasmid DNA in aqueous two-phase systems
}

\begin{abstract}
In this paper, the partition of plasmid DNA (pDNA) in polyethylene glycol (PEG) 300 and di-potassium hydrogen phosphate aqueous two-phase systems (ATPS) under gravity separation was investigated. The influence of temperature $\left(20\right.$ and $\left.30{ }^{\circ} \mathrm{C}\right)$ and mode of phase separation $(401060 \%(\mathrm{w} / \mathrm{w})$ lysate concentrations) on the pDNA partition behaviour was studied. At $20{ }^{\circ} \mathrm{C}, 70.7 \%$ of pDNA partitioned to the top phase while the recoveries in the interface and bottom phase were comparatively small. At $30{ }^{\circ} \mathrm{C}$, the partition had switched from a top phase preference to an interface preference where $73.9 \%$ of pDNA was recovered. The distribution of pDNA between the top phase and interface is effectively time-dependent during gravitational phase separation. Systems with lysate concentrations between 40 and $50 \%(\mathrm{w} / \mathrm{w})$ separated with a continuous bottom phase and a dispersed PEG-rich top phase. For ATPS with 55 and $60 \%(\mathrm{w} / \mathrm{w})$ lysate, the top phase was continuous and the bottom phase was dispersed.
\end{abstract}

Keyword: Interfacial partition; Plasmid DNA; Aqueous two-phase systems; Top phase; Bottom phase 